EUROPA REGIONUM TOM XXIII ROK 2015

DOI: $10.18276 / \mathrm{er} .2015 .23-11$

\author{
LEONID WOROBJOW, ILONA KORDEK \\ Zachodniopomorski Uniwersytet Technologiczny w Szczecinie
}

\title{
Długoterminowa strategia zarządzania marką „Szczecin Floating Garden 2050”
}

\section{Wprowadzenie}

W

ciagu ostatnich kilkunastu lat w Polsce możemy zaobserwować szybki rozwój marketingu terytorialnego. Przed wieloma regionami i miastami otwierają się nowe możliwości rozwoju i promocji. Coraz więcej miast decyduje się na podniesienie swojej atrakcyjności przez zbudowanie i wdrażanie długoterminowej strategii marki miasta. W swoich działaniach urzędy miast wykorzystują przeróżne instrumenty marketingowe, służące m.in.: komunikacji z mieszkańcami, inwestorami i turystami, oraz wdrażaniu tych instrumentów i budowaniu solidnej marki miasta. Działania te są ukierunkowane na stworzenie nowego, lepszego wizerunku miejsca, a co za tym idzie - zainteresowanie potencjalnych inwestorów i turystów, a także wzbudzenie w mieszkańcach ducha przynależności do miejsca zamieszkania.

Marketing terytorialny jest wynikiem poszerzenia i pogłębienia obszaru zainteresowań marketingu, jego interpretacji jako procesu wymiany wartości (korzyści) pomiędzy różnymi podmiotami czy grupami. Marketing miejsca, bo tak określa się też marketing terytorialny, jest jednym z nowych obszarów zainteresowań marketingowych ${ }^{1}$.

${ }^{1}$ A. Szrominik, Marketing terytorialny jako atrybut rynkowej orientacji miast i regionów, w: A. Grzegorczyk, A. Kochaniec (red.), Kreowanie wizerunku miast, Wyższa Szkoła Promocji, Warszawa 2011. 
Aby miasto stało się marką, potrzeba bardzo wielu zabiegów promocyjnych, w których tworzenie zaangażowane są władze miasta. Stworzenie silnej marki miasta związane jest $\mathrm{z}$ obietnicą i dotrzymaniem jej przez władze. Jednak, aby mogło to zaistnieć, potrzebne jest opracowanie strategii marketingowej miasta. Dobrze opracowana strategia marketingowa miejsca powinna określać działania, cele i środki potrzebne do uzyskania zamierzonego efektu. Strategia marketingowa miasta i zarządzanie jego marką jest działaniem długofalowym, które powinno być kontynuowane przez następujące po sobie kadencje władz miejskich. Realizacja strategii marketingowej miasta w perspektywie tylko jednej lub kilku kadencji władz jest nieefektywna i nie prowadzi do pozytywnych efektów wdrażania marki miejsca, jakimi są: rozpoznawalność miasta, napływ ludności czy też pozyskiwanie kapitału zewnętrznego i realizacja nowych inwestycji na jego terenie.

\section{Metody i analiza}

Oferta marketingowa miasta ma na celu zachęcenie do skorzystania z oferowanych przez nie usług, zainteresowania potencjalnego klienta zewnętrznego i przyciagnięcie jego kapitału na obszar miasta. Mogą to być, na przykład placówki turystyczne, punkty gastronomiczne, walory środowiska przyrodniczego i dziedzictwa kulturowego ${ }^{2}$.

Ważnym elementem dla marketingu terytorialnego jest promocja, która odgrywa ważną rolę konkurencyjną pomiędzy poszczególnymi jednostkami terytorialnymi, rywalizującymi o fundusze pomocowe, inwestorów, turystów itp. Celami promocji są formy komunikacyjne, przy pomocy których jednostka terytorialna, taka jak miasto, przekazuje informacje i określa swój wizerunek marki, budowany wśród podmiotów, do których kieruje działania.

Mówiąc o rynkach docelowych w marketingu terytorialnym miast i regionów musimy odpowiedzieć sobie na pytanie „dla kogo?”. Rynki docelowe najprościej podzielić można na różne grupy podmiotów, w tym turystów i wizytujących - kreujących swoje wyobrażenia dotyczące miasta pod wpływem subiektywnych odczuć oraz poprzez bezpośredni kontakt z miastem, jego infrastruktura, mieszkańcami, personelem (szeroko rozumianym, jako np.: pracownicy jednostek samorządu terytorialnego, pracownicy przedsiębiorstw produkcyjnych i usługowych). W ten sposób

${ }^{2}$ A. Sekuła, Marketing terytorialny, w: M. Daszkowska (red.), Marketing. Ujęcie systemowe, Wydawnictwo Politechniki Gdańskiej, Gdańsk 2005. 
tworzy się interakcja, która w turystach oraz wizytujących wytwarza pozytywny lub negatywny wizerunek miasta.

\section{Dyskusja}

Współczesnym atutem Szczecina jest ogromna przewaga terenów zielonych na terytorium miasta, a jego wyróżniającymi elementami są drzewa magnolii, w takiej ilości niespotykanie nigdzie indziej w Europie, oraz zapach czekolady unoszący się nad miastem z Przedsiębiorstwa Przemysłu Cukierniczego Gryf SA.

Wszystkie wymienione wyżej składniki kształtują ład przestrzenny Szczecina, który również w znacznym stopniu zależy od historycznej struktury funkcjonalno-przestrzennej, a także od specyficznego ukształtowania odcinka Odry. Dolina rzeki jest korytarzem ekologicznym o randze międzynarodowej. Jako jedna z czterech istniejących na terenie Polski umożliwia migrację roślin, zwierząt lub grzybów. Równocześnie stanowi jeden z elementów europejskiej sieci ekologicznej ECONET-PL. Tereny zielone niespotykane w innych miastach Polski wyróżniają Szczecin i stwarzają okazję do budowania strategii marketingowej opartej $\mathrm{m}$. in. na podkreślaniu ich znaczenia oraz wykorzystania w tworzeniu nowego ładu przestrzennego. Szczecin otoczony jest przez trzy puszcze, łączące się z kompleksami zieleni w mieście: Wkrzańską od północy, Bukową od południa i od wschodu Goleniowską. Duży udział wód w powierzchni miasta ma, prócz delty Odry, jezioro Dąbie $\left(56 \mathrm{~km}^{2}\right)$, pod względem powierzchni zajmujące czwarte miejsce w kraju ${ }^{3}$.

Na przestrzeni lat zwiększeniu uległa liczba organizacji pozarządowych, takich jak fundacje, stowarzyszenia, organizacje społeczne. Zjawisko to jest związane ze zwiększeniem aktywności społecznej, świadomości obywatelskiej w małych społecznościach, cechujące się pozytywnym nastawieniem do zrzeszania się mieszkańców Szczecina w celu przeróżnych inicjatyw społecznych. Współpraca polega na promowaniu działań, organizacji wspólnych przedsięwzięć i realizacji różnorodnych zadań publicznych, co stanowi ważne ogniwo wspomagające rozwój miasta.

Szczecin, jako jedno z większych miast w regionie Pomerania, rozpoczął działania związane ze stworzeniem marki miejsca w 2007 roku, powołał grupę planistyczną i skoordynował działania różnych podmiotów, by stworzyć spójną długoterminową strategię zarządzania marką miasta Szczecin. Wtedy to ogłoszono prze-

3 „Szczecin_dla Ciebie”, Strategia Rozwoju Szczecina 2025, 19 grudnia 2011, http://bip.um.szczecin.pl/umszczecinbip/files/3682229E85BD4DBB9A77B734E3313C28/_Strate gia_Rozwoju_Szczecina_2025.pdf. 
targ na opracowanie strategii marki Szczecina, w którym zostało wyłonione konsorcjum Corporate Profiles Consulting - firmy zajmującej się szeroko rozumianym doradztwem w zakresie marketingu. Firma ta zajmuje się także kompleksowym doradztwem dla marek BNA (Brand Nature Access) specjalizującej się w tworzeniu systemów identyfikacji wizualnej. Trzy fazy projektu miały dążyć do stworzenia marki dla miasta Szczecin, obejmowały one kolejno:

Fazę analitycznq - polegającą na przeprowadzeniu badań rynkowych, pozyskiwaniu informacji niezbędnych do stworzenia strategii marketingowej, analizie służącej do odtworzenia wizerunku Szczecina. Reasumując: w początkowej fazie podjęto działania diagnozujące kondycję obecnej marki oraz opracowano raport otwarcia potrzebny do podjęcia dalszych prac strategicznych. W fazie analitycznej zostały przeprowadzone badania obejmujące różne grupy docelowe np.: badania ankietowe wśród mieszkańców oraz turystów, inwestorów, spotkania i konsultacje z ekspertami, przedstawicielami świata nauki, mediów, samorządowców (panele eksperckie).

Fazę koncepcyjna - obejmującą powstanie wstępnej koncepcji dla marki Szczecin, rekomendacji do pozycjonowania jej wśród innych miast oraz projekty systemu identyfikacji wizualnej. Podstawą do fazy koncepcyjnej była stworzona w 2006 roku „Polityka Promocji Szczecina” stworzona i uchwalona przez Radę Miasta. Projekt ten zakładał następujące cele strategiczne, które miały zostać osiagnnięte poprzez konkretne działania promocyjne:

- osiągnięcie standardu miejskich funkcji społeczno-gospodarczych właściwego dla ponadregionalnego centrum;

- stworzenie zróżnicowanej, zrównoważonej i efektywnej gospodarki o dużym potencjale wzrostu;

- stworzenie warunków do osobowego i społecznego rozwoju mieszkańców;

- ochrona oraz wykorzystanie walorów przyrodniczych, rewitalizacja i rozwój przestrzeni miejskiej.

Faze implementacyjnq - w której opracowano praktyczne wytyczne i wskazówki strategii komunikacji marki, jak i potrzebną dokumentację.

Badania przeprowadzone przez firmę Millward Brown przedstawiły najważniejszą cechę miasta, wyróżniającą je spośród innych, którą jest zieleń miejska i jej ogromny udział w przestrzeni geograficznej miasta. To dzięki tej cesze Szczecin posiada walory aktywnego miasta przyjaznego mieszkańcom, 
w którym można się wyciszyć i wypocząć. Kolejnymi wnioskami w przeprowadzonym badaniu jest fakt, iż miastu brakowało atrakcji przyciągających turystów i mieszkańców oraz impulsu do tworzenia konkretnych działań. Atutem Szczecina jest także jego ,potencjał duchowy” przejawiający się tworzeniem pozytywnych subiektywnych odczuć turystów odkrywających miasto, które urzeka swoimi wdziękami. Najbardziej rozpoznawalnymi miejscami Szczecina są Wały Chrobrego, stocznia i port. Mieszkańcom innych regionów Polski Szczecin kojarzy się z bliskością morza, dużą liczbą obcokrajowców, najpewniej z powodu odwiedzającej go ludności niemieckiej, oraz łatwym dostępem do Berlina.

Szczecin był obciążony wizerunkiem miasta portowego i przemysłowego, co okazało się barierą dla rozwoju oraz skutkowało zastojem i brakiem inwestycji. W ostatnich latach obserwować można pozytywne zmiany wyrażające się poprzez inwestycje (kappielisko Arkonka, filharmonia, hala sportowa przy ulicy Zawadzkiego). Miasto wyróżnia się położeniem geopolitycznym, różnorodnością ludzi zarówno obcokrajowców, - jak i jego mieszkańców oraz, co najważniejsze, zielenią miejską i terenami wodnymi zajmującymi wspólnie ponad połowę powierzchni miasta. Te wnioski posłużyły firmie BNA do przedstawienia wizji „pływających ogrodów”, która obecnie jest kierunkiem, w którym zmierzają wszystkie zmiany w mieście. To właśnie niewykorzystywane zasoby, zieleń oraz woda wyznaczają teraźniejszą strategię miasta, w oparciu o którą skorelowane będą wszystkie działania ekip kolejno rządzących w Szczecinie.

Analiza przeprowadzona $w$ ramach tworzenia marki dla miasta Szczecin wykazała, iż nie można kreować jej ze względu na przeszłość historyczną czy też ówczesne wydarzenia. Efektem tych ustaleń było przyjęcie założenia, by kreować markę w oparciu o to, jak miasto może wyglądać w przyszłości. Zaczęto budowanie wizji miasta, która opierała się na wykorzystaniu walorów naturalnych, a w efekcie powstała marka Szczecin Floating Garden, z perspe-ktywą długookresowego rozwoju miasta do 2050 roku. Projekt ten, jako strategiczny plan rozwojowy zakłada, iż Szczecin połączy w sobie dynamikę i kreatywność metropolii oraz przestrzeń i spokój miejsca przyjaznego ludziom i naturze.

Ostatnią wartością ważną dla realizacji zadań strategicznych jest szacunek dla ludzi i przyrody, przejawiający się harmonią wzajemnych powiązań, mających na celu kształtowanie przyszłego wyglądu miasta, zachowania i podkreślenia zieleni miejskiej w kształtowaniu ładu przestrzennego, zgodnie z zasadami zrównoważonego rozwoju i ekologii. 
Bardzo ważną rolę w długoterminowej strategii zarządzania marką „Szczecin Floating Garden 2050" odgrywa System Identyfikacji Wizualnej (SIW) miasta. System ten ma za zadanie odróżnić miasto specjalnie opracowaną kolorystyką, kształtami wywołującymi skojarzenia ze Szczecinem. Uroczysta premiera Systemu Identyfikacji Miejskiej odbyła się w kwietniu 2008 roku i trwa ona niezmiennie w obecnej formie ${ }^{4}$.

Spójny SIW posiada cztery podstawowe znaki spełniające określone funkcje. Głównym jest logo - znak wizji Floating Garden 2050 (rys. 1). Znak ten jest zapisanym w Międzynarodowym Alfabecie Fonetycznym (IPA) wizerunkowym logotypem miasta Szczecin w założeniu mającym budować postrzeganie miasta przez pryzmat wizji Floating Garden 2050. W znaku wizji znajduje się data 2050 oraz słowo „project” ukazujące systemowe podejście do wdrożenia. By zwrócić uwagę na fakt, że rzeczy wielkich nie da się zrobić w krótkim okresie, symboliczny horyzont czasowy zakreślono do roku 2050. Tak długi zakres czasowy osadza wizję w rzeczywistości, tworząc cel odróżniający go od marzeń.

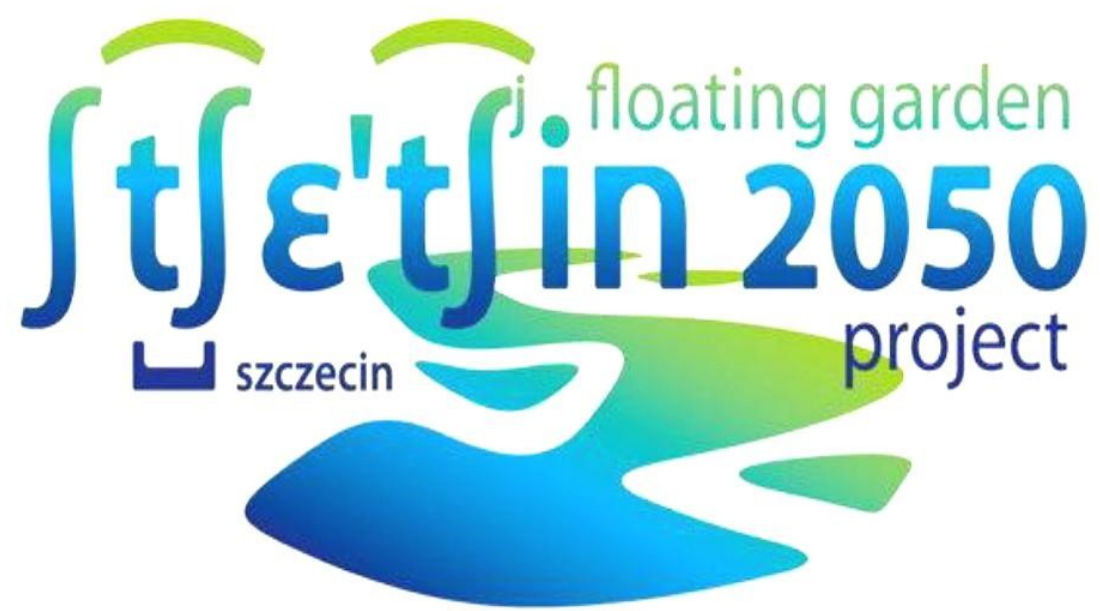

Rysunek 1. Logo główne projektu „Szczecin Floating Garden 2050” Źródło:http://www.szczecin.eu/marka/system_identyfikacji.

Drugim symbolem uzupełniającym symbolikę marki Szczecin Floating Garden jest logo Urzędu Miasta Szczecin (rys. 2). Unowocześniony wizerunek gryfa odwołuje się do historycznego herbu rodu Gryfitów i statutowego herbu Miasta Szczecin (rys. 3) i inicjuje działania nakreślone w strategii marki. Stoso-

${ }^{4}$ „Szczecin_dla Ciebie” Strategia Rozwoju Szczecina 2025... 
wane w związku ze wspieraniem aktywności mieszkańców, znakowaniem wydarzeń kulturalnych i sportowych, aktywności Urzędu związanych z zarządzaniem Miastem, jak i wydarzeń objętych Honorowym Mecenatem Miasta. Logo Urzędu Miasta Szczecin jest bardzo trafnym projektem, który poprzez odwołanie do tradycyjnych barw stosowanych w oznaczeniach miasta zaskakuje dokładnością wykonania i dbałością o historię z uwzględnieniem kultury.

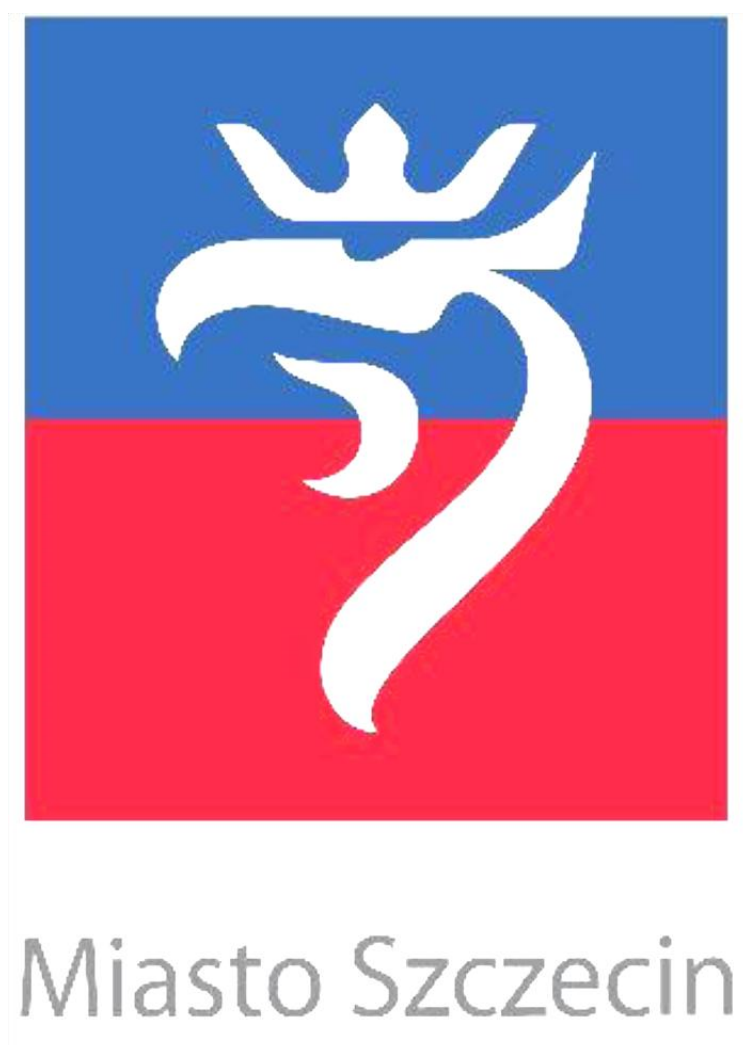

Rysunek 2. Logo Urzędu Miasta Szczecin

Źródło: http://www.szczecin.eu/marka/system_identyfikacji.

Kolejnym wśród podstawowych znaków jest herb Szczecina. Przedstawia on niebieską tarczę herbową z żółtym obramowaniem. Po środku tarczy usytuowana jest głowa gryfa ukoronowanego, nawiązującego do symbolu dynastii Gryfitów. Postać obecnego herbu została ustanowiona przez Radę Miejską w Szczecinie. Stosowanie Herbu Miasta Szczecin jest dozwolone w przypadku 
znakowania imprez objętych Honorowym Patronatem Prezydenta Miasta, jest też coraz cześsciej spotykane na oznakowaniu komunikacji miejskiej.

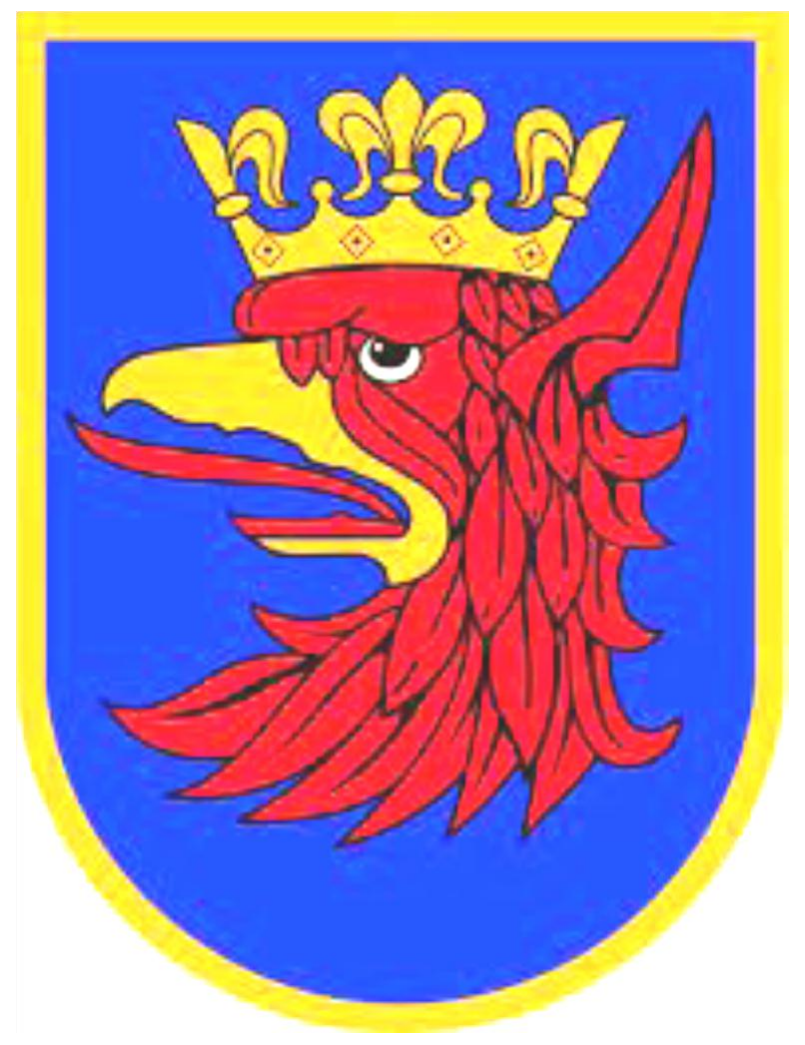

Rysunek 3. Herb Miasta Szczecin

Źródło: http://www.szczecin.eu/marka/system_identyfikacji.

Ostatnim z podstawowych znaków graficznych określających wizerunek Szczecina jest logo regat wielkich żaglowców The Tall Ships Races 2013 (rys. 4). Znak ten został zarejestrowany i może być stosowany przez miasto do celów komercyjnych. Porty pełniące rolę gospodarczą otrzymują licencję na jego wykorzystywanie pod warunkiem spełniania wszystkich ustaleń określonych w umowie. Miasto będące gospodarzem regat udziela także pozwoleń na używanie tytułów lub podtytułów związanych z regatami oraz logo, wszystkie wymienione pozwolenia mogą być wykorzystywane na towarach handlowych przeznaczonych do sprzedaży ogólnej. Logo The Tall Ship Races 2013 łączy w sobie 
Logo Urzędu miasta Szczecin i rysunek trzech białych żaglowców układających się na nim, w kolejności od najmniejszego do największego.

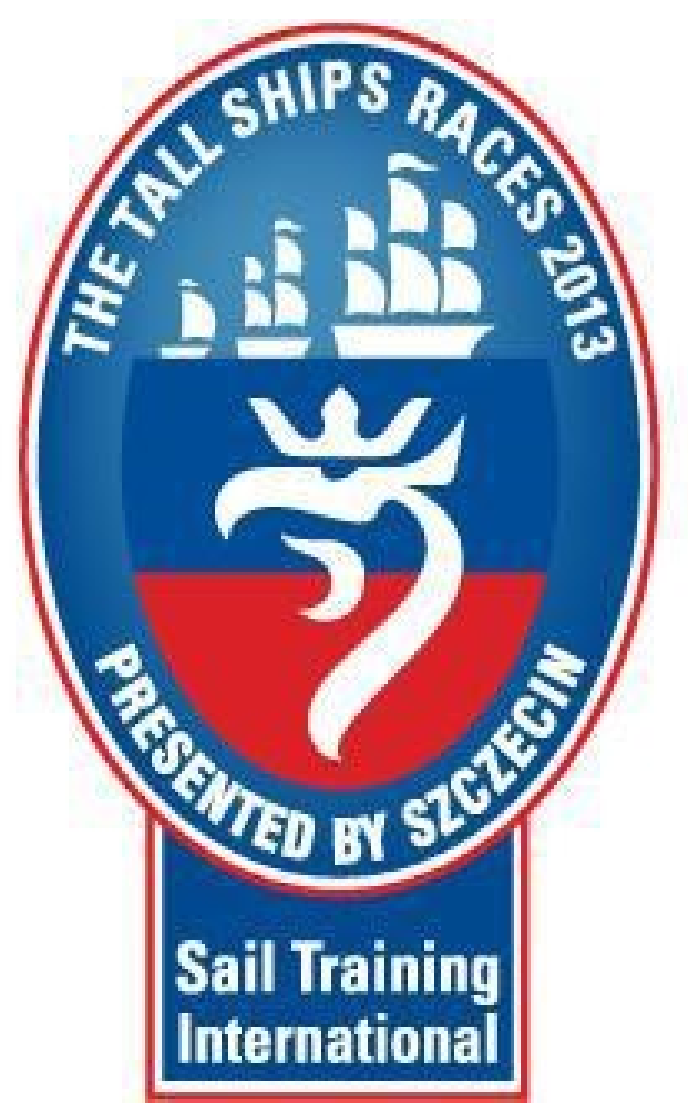

Rysunek 4. Logo Regat The Tall Ship Races 2013

Źródło: http://www.szczecin.eu/marka/system_identyfikacji.

W Systemie Identyfikacji Wizualnej miasta Szczecin ważnym elementem jest także typografia, która pozwala osiagnąć poziom maksymalnej spójności pomiędzy wszystkimi wprowadzonymi materiałami promocyjnymi. Jest to czcionka - zarówno w podstawowej, jak i pogrubionej wersji.

Ostatnim omawianym zagadnieniem są graficzne elementy uzupełniające, zaprojektowane w SIW dla utrzymania spójnego charakteru projektowanych przekazów. Budują one ponadto indywidualny, nowoczesny styl miasta we wszelkich formach komunikacji wizualnej. 
Urząd Miasta Szczecin zlecił także opracowanie Katalogu Systemu Identyfikacji Wizualnej, w którym można poznać wizję graficzną miasta wraz z dokładnym opisem nośników i danych technicznych przekazujących informacje o charakterze miejskim. Opisują one barwy i krój pisma systemu, konstrukcję kierunkowskazów oraz piktogramów informacyjnych, określają wysokości i warianty dostępnych słupów informacyjnych, tablic z nazwami ulic czy numeracją budynków miejskich, oznakowania miejsc wyjątkowych historycznie (zabytki architektoniczne, pomniki), kulturalnie i środowiskowo (skwery, parki). Wszystkie te działania związane z SIW mają za zadanie ułatwienie poruszania się po mieście, a także podwyższenie poziomu bezpieczeństwa.

Długoterminowa Strategia Zarządzania Marką Floating Garden 2050 w swojej istocie zakładała przede wszystkim działania aktywne, budowanie marki miasta Szczecin poprzez różnorodne przedsięwzięcia na wielu płaszczyznach.

Działania propagandowe maja na celu wywołanie w odbiorcach konkretnych zachowań i uczuć, które są omawiane i strategicznie zaplanowane przez firmy tworzące strategię marketingową miasta. Działaniom tym towarzyszy rozgłos, który jest nieodłącznym ich elementem. Prócz omówionych wcześniej działań z zakresu informowania i akcentowania nowych znaków i wyróżników marki zrealizowano też inne przedsięwzięcia takie jak np.: kampania outdorowa zatytułowana „Most Visionary City In Europe” prezentująca slogan miasta i rozmyte logo dające jedynie wskazówki i luźne skojarzenia z marką Floating Garden 2050. Miasto współorganizowało wystawę prac tematycznych „Szczecin Floating Garden 2050", otwartą w siedzibie Wydziału Architektury Zachodniopomorskiego Uniwersytetu Technologicznego w Szczecinie. Wystawa przedstawiała wizję studentów Wydziału ekologicznego zagospodarowania przestrzeni miejskiej. Jedną z najważniejszych imprez prowadzonych pod patronatem marki „Szczecin Floating Garden 2050” jest finał regat The Tall Ships Races, który odbył się w Szczecinie już dwa razy.

Przykłady blogów, stron internetowych, spotów kampanii internetowych można mnożyć w nieskończoność. Szczecin pod względem wykorzystania internetu jako środka komunikacji spisał się wzorowo. Strony te nie są tworzone przez Urząd Miasta, a przez pasjonatów Szczecina, jego aktywnych mieszkańców i tworzą ogromny potencjał, który dobrze ukierunkowany prowadzi do rozgłosu. 


\section{Podsumowanie}

Na zakończenie stwierdzić można, że marketing terytorialny jest to dziedzina stosunkowo nowa zawierająca w sobie elementy wielu dyscyplin naukowych, co czyni z niej dziedzinę multidyscyplinarną. Na ocenę podjętych działań bardzo ważny wpływ miała zarówno historia Szczecina od lat najdawniejszych, jak i dane statystyczne, które przedstawiono za pomocą wskaźników ukazujących: liczbę ludności faktycznie zamieszkałej i zameldowanej na pobyt stały oraz tymczasowy na terenie Szczecina, współczynnik feminizacji w mieście, a także opis struktury ludności ze względu na kohorty wiekowe.

Po zapoznaniu się z długookresową strategią marki „Szczecin Floating Garden 2050" można stwierdzić, że jej stworzenie ma i nadal będzie miało pozytywny wpływ na przyciaganie kapitału obcego do miasta, a co za tym idzie poprawieniu sytuacji gospodarczej, wskaźników ekonomicznych i demograficznych w ujęciu długookresowym.

\section{Bibliografia}

Kaczmarek J., Zarzadzanie wizerunkiem miasta - uwagi heurystyczne, w: J. Słodczyk, E., Szafranek (red.), Studia miejskie. Koncepcje i instrumenty zarzqdzania procesami rozwoju i rewitalizacji miast. Wydawnictwo Uniwersytetu Opolskiego, Opole 2010.

Kordek I., Dtugoterminowa strategia zarzadzania marka ,,Szczecin Floating Garden 2015", praca licencjacka pod kier. Prof. dr hab. Leonida Worobjowa, Zachodniopomorski Uniwersytet Technologiczny w Szczecinie, Szczecin 2014.

Sekuła A., Marketing terytorialny, w: Daszkowska M. (red.), Marketing. Ujęcie systemowe, Wydawnictwo Politechniki Gdańskiej, Gdańsk 2005.

Szromnik A., Marketing terytorialny jako atrybut rynkowej orientacji miast $i$ regionów, w: Grzegorczyk A., Kochaniec A. (red.), Kreowanie wizerunku miast, Wyższa Szkoła Promocji, Warszawa, 2011.

Szromnik A., Marketing terytorialny. Miasto i region na rynku, Wolters Kulwer, Warszawa 2007.

„Szczecin_dla Ciebie” Strategia Rozwoju Szczecina 2025, 19 grudnia 2011, http://bip.um.szczecin.pl/umszczecinbip/files/3682229E85BD4DBB9A77B734E3313C2 8/_Strategia_Rozwoju_Szczecina_2025.pdf. 


\section{Long-term strategy of brand management on the example of „Szczecin Floating Garden 2050”}

\section{Summary}

The aim of this article is to present a long-term strategy of ,Szczecin Floating Garden 2050" brand management and an evaluation of actions undertaken by City Hall of Szczecin. Moreover, the article is a comprehensive synthesis of existing studies on brand building of Polish cities and their marketing strategies.

To achieve the objective following tasks have been completed: characteristics of territorial marketing in Poland has been presented; characteristics of the sociodemography of the city of Szczecin has been presented; an analysis of the marketing strategy of the city of Szczecin has been conducted. In the paper the literature on territorial marketing has been used. An important source of information were also documents: „,Szczecin 2025 Development Strategy”, „Communication and Implementation of The Value of the City of Szczecin" and "Visual Identification System Catalog” of the city of Szczecin 